\title{
Phenotypic Stability for Selected Traits of Some Cowpea Lines in Nigerian Agro-ecologies
}

\author{
Mohammed F. Ishiyaku ${ }^{1}$, Victoria M. Yilwa ${ }^{2} *$, Bir B. Singh ${ }^{3}$, Olusoji O. Olufajo ${ }^{4}$, Aminu A. Zaria ${ }^{1}$ \\ ${ }^{1}$ Department of Plant Science, Institute for Agricultural Research Ahmadu Bello University, PMB 1044 Zaria, Nigeria \\ ${ }^{2}$ Department of Biological Sciences, Nigerian Defence Academy, PMB 2109 Kaduna, Nigeria \\ ${ }^{3}$ International Institute of Tropical Agriculture, Kano Station Sabo Bakin Zuwo Road, PMB 1032 Kano, Nigeria \\ ${ }^{4}$ Department of Agronomy, Institute for Agricultural Research, Ahmadu Bello University, PMB 1044 Zaria, Nigeria
}

\begin{abstract}
Eight advanced breeding lines of cowpea [Vigna unguiculata (L.) Walp.] were evaluated in a multi-environment trial for phenotypic stability of grain yield, maturity and grain size. There was highly significant genotype $\mathrm{x}$ environment interaction for all traits. Simple correlation coefficient was computed to ascertain the level of relationship between stability parameters and agronomic traits. Line IT93K-452-1 was identified as most stable genotype and can be grown all over the Nigerian cowpea belt. The line IT90K-503-1 was the most unstable genotype in terms of grain yield and was also nonresponsive to the environment. However, it is environment specific. IT93K-452-1 has relatively stable maturity across environments. The result suggests that IT93K-452-1 will mature around the average of 65 days irrespective of the location in Nigeria. Lines IT95K-1455 and IT90K-503-1, whose stability parameter values were high, means that in respect of maturity, they are photo-thermo sensitive. They can mature early or delayed depending on the photo-thermal environment. However, lines such as IT93K-273-2-1, IT93K-129-4, IT93K-452-1 and IT86D-719 are photo-thermo insensitive. Line IT93K-1543 was identified as the most desirable genotype in terms of grain size. This is followed by IT93K-452-1. The line IT90K-503-1 had small but unstable seed size. This work identified IT93K-452-1 and IT93K-273-2-1 as the most stable genotypes for yield and maturity. Grain yield was highly positively correlated with $b_{i}$ and $R^{2}$ but was negatively correlated with $S d^{2}{ }_{i}$. Maturity was negatively highly correlated with $b_{i}, W_{i}$, and $C V_{i}$. Grain size on the other hand is not correlated with any of the parameters.
\end{abstract}

Keywords Agro-ecology, Cowpea, Grain size, Grain yield, Multi-environment, Phenotypic stability, Photo-thermo sensitive, Trials

\section{INTRODUCTION}

Cowpea [Vigna unguiculata (L.) Walp.] is an important source of cheap protein for human (Quin 1997) and fodder for livestock (Tarawali et al. 1997). The crop, through its nitrogen fixing ability, improves the fertility of the marginal soils characteristic of the semi-arid ecology (Carsky et al. 2002; Bado et al. 2006). Cowpea has been reported to contribute between 35 and $40 \mathrm{~kg}$ nitrogen per hectare/ha in a cowpea-millet rotation (Bagayoko et al. 1998). The crop is also a source of income especially for women who prepare and sell several food products from the crop (Ishiyaku 2001; Ibro et al. 2006). Nigeria, with annual production of 2.17 million tons from 5 million ha (FAOSTAT 2002), is the largest producer and consumer of cowpea in the world. Even with this seemingly huge production, Nigeria continues to suffer deficit in its national cowpea requirement. This deficit has been put as between 200,000 to 500,000 metric tons annually (Langyintuo et al. 2003). Nigeria's deficit for cowpea requirement is mostly met through imports from neighboring countries such as Niger, second major producer in

Received February 10, 2017; Revised April 17, 2017; Accepted April 30, 2017; Published June 1, 2017

*Comesponding author Victoria M. Yilwa, vmyilwa@yahoo.com, Tel: +234-8039410477 
the world (Langyintuo et al. 2003). Other major world cowpea producers include Brazil, Burkina Faso and Cameroon. Cowpea is also important in Eastern and Southern Africa such as Sudan, Uganda, Mozambique, Tanzania, Mali and Senegal. Deficit in Nigeria's national crop requirement including cowpea has been attributed to growth in population, use of varieties with low yield potential among others (Mustapha 2003). Mustapha (2003) identified genetic improvement as one of the most sustainable and environment-friendly means of providing more food to the teaming population of Nigeria.

In the last two decades the Institute for Agricultural Research (IAR), Ahmadu Bello University, Zaria, in collaboration with the International Institute of Tropical Agriculture (IITA) Ibadan has developed several cowpea varieties with high yield potential and qualities acceptable to the Nigerian consumers. However, these varieties have now lost their genetic superiority as a result of susceptibility to new production and or processing constraints such as susceptibility to striga (Striga hermonthica) (Emechebe and Lagoke 2002), bruchid (Callosobruchus maculatus), ease of processing for food, etc. In addition, great advances have been made in the understanding of the genetics of resistance to many diseases (such as bacterial blight, scab, and septoria leaf spot); pests (such as aphids and thrips); parasitic flowering plants (such as striga and alectra) and drought. Comprehensive review of the genetics of these traits is given in Fery and Singh (1997) and Singh (2002). The advances made in the genetics of cowpea has led to the development of more superior genotypes with over $20 \%$ higher yield potential and better quality traits such as shorter cooking time and increased protein content than in the older varieties (Singh et al. 2002). However, having genotypes with specific resistance and/or tolerance genes is not enough. Results of multienvironment evaluation of varieties of crops (Ado and Ishiyaku 1999) have indicated that some varieties tend to interact with specific test sites and exhibit unexpected performance in some locations while others show relatively stable yields across environments. The degree of such interaction between a variety and the different environments determines whether or not a variety is released to a wide or narrow production belts. Only after ascertaining the adaptability of such genotypes to specific locations in which they would be grown will they be released to farmers for commercial production with high degree of confidence with regard to their productivity. Therefore, it is of paramount importance to the breeder, knowledge of how widely across various ecologies/niches can genotypes developed be grown.

Several methods for determining performance stability and adaptation of varieties have been proposed. The parametric statistics used to measure stability of crops include Finlay and Wilkinson's (1963) $b_{i}$, the regression coefficient of varieties on environmental index. The environmental index is estimated as the difference between the marginal means of an environment and the overall mean. The $b_{i}$ classifies genotypes according to their stability under different conditions. A genotype is defined as stable when its $b_{i}$ is equal to zero. Eberhart and Russell (1966) proposed that stable varieties are those with high mean performance, $b_{i}=1$ and the average deviation from regression $S d^{2}$ equal to zero. $S d^{2}$ is used as a measure of phenotypic stability of the tested genotypes. Francis and Kannenberg (1978) used the coefficient of variability $C V_{i}$ of the variety across environment mean- a variety is stable if its $C V_{i}$ value is relatively low. $C V_{i}$ measures genotype stability. The contribution of the variety variance to the total genotype $\mathrm{x}$ location variance was considered as measure of stability. The lower the relative contribution of a genotype to the $\mathrm{G} \times \mathrm{E}$ variance, the more stable $W_{i}$ (Wricke 1962). $W_{i}$ refers to the relative contribution of each genotype to $\mathrm{G} \times \mathrm{E}$ interaction effects across all environments. It determines stability. Low $W_{i}$ indicates stable genotype. Lin et al. (1986) in their analysis of the relative efficiency of these parameters in estimating stability concluded that the relevance of these parameters depends on the nature of the dataset.

Our aim is to report the phenotypic stability for grain yield, maturity and seed size of some advance cowpea breeding lines evaluated across the Nigerian agro-ecologies in order to identify most stable lines as well as to select stability parameters that are most related with the agronomic traits. 


\section{MATERIALS AND METHODS}

\section{Accessions}

Nine elite breeding lines including a check were evaluated in 1996 and 1997 at different locations. List of the varieties and their brief description is given in Table 1.

\section{Evaluation locations}

Evaluation of the varieties was conducted in nine different locations, spreading across the different ecologies in which cowpea is likely to be grown in Nigeria. The description of these locations is presented in Table 2.

\section{Experimental design, crop management and data collection}

Experiment in each of the environments was laid out as a randomized complete block design replicated three times. Plot size was 4 rows of $4 \mathrm{~m}$ length. Spacing was $75 \mathrm{~cm}$ and $20 \mathrm{~cm}$ for between rows and within rows, respectively. There were two stands per hill. The two middle rows were used for data collection. All recommended management practice for cowpea was observed. Maturity was scored as the number of days taken from sowing to when $90 \%$ of pods in the net plot reached maturity. At maturity, plants were harvested and threshed. Total grain harvested from each plot was weighed using a balance $(0.1 \mathrm{~g}$ sensitive $)$ and recorded as grain yield per plot. This weight was then converted to per hectare basis. Grain size was measured as the weight of 100 grains after sun drying. An average from three samples was used in the analysis to obtain a value for each plot. The data was then subjected to analysis of variance using the SAS statistical package (SAS Institute 1996). Means were separated following the StudentNeuman-Keuls. Stability parameters, $b_{i}$ of Finlay and Wilkinson (1963), $C V_{i}$, of Francis and Kannenberg (1978), $S d^{2}{ }_{i}$ of Eberhart and Russel (1966) and $W_{i}$ of Wricke (1962) were estimated for each genotype. Varieties were categorized as stable or not on the basis of these parameters. Association between the four stability parameters on one side and the three agronomic traits, yield, maturity and

Table 1. List of cowpea varieties evaluated in the early maturing multi-environment trial in 1996 and 1997 rainy season, Nigeria.

\begin{tabular}{lll}
\hline \hline \multicolumn{1}{c}{ Genotypes } & Development Institute & \multicolumn{1}{c}{ Description } \\
\hline IT93K-452-1 & IITA, Kano Station & Semi-erect, early, white grain, black eye \\
IT95K-1543 & IITA, Kano Station & Semi-erect, early, brown grain \\
IT93K-273-2-1 & IITA, Kano Station & Semi-erect, early \\
IT93K-129-4 & IITA, Kano Station & Erect, early \\
IT86D-719 & IITA, Kano Station & Check, erect, early, white grain, brown eye \\
IT934K-410-2 & IITA, Kano Station & Semi-erect, early \\
IT95K-1455 & IITA, Kano Station & Erect, early, white grain \\
IT90K-503-1 & IITA, Kano Station & Semi-erect, early, white grain \\
\hline
\end{tabular}

Table 2. Agro-ecological description of test locations used in the evaluation of early maturing cowpea varieties for adaptation in Nigeria.

\begin{tabular}{|c|c|c|c|c|c|c|c|c|c|c|c|}
\hline \multirow{2}{*}{ Description } & \multicolumn{11}{|c|}{ Locations } \\
\hline & Abeokuta & Ile-Ife & Bauchi & Gombe & Kano1 & Kano2 & Mokwa & Samaru1 & Samru2 & Ibadan & Uyo \\
\hline Coordinate & $\begin{array}{ll}7^{\circ} & 10^{\prime} \mathrm{N}: \\
3^{\circ} & 20^{\prime} \mathrm{E}\end{array}$ & $\begin{array}{lll}7^{\circ} & 28 & \\
4^{\circ} & 33 & \mathrm{~N} \\
\end{array}$ & $\begin{array}{l}10^{\circ} 18^{\prime}, \mathrm{N} \\
9^{\circ} 50^{\prime}, \mathrm{E}\end{array}$ & $\begin{array}{l}10^{\circ} 16^{\prime}, \mathrm{N} ; \\
11^{\circ} 10^{\prime}, \mathrm{E}\end{array}$ & $\begin{array}{l}12^{\circ} 01^{\prime}, \mathrm{N} ; \\
8^{\circ} 30^{\prime \prime} \mathrm{E}\end{array}$ & $\begin{array}{l}12^{\circ} 01^{\prime}, \mathrm{N} ; \\
8^{\circ} 30^{\prime}, \mathrm{E}\end{array}$ & $\begin{array}{ll}9^{\circ} & 17^{\prime \prime} \mathrm{N} ; \\
5^{\circ} & 03^{\prime \prime} \mathrm{E}\end{array}$ & $\begin{array}{l}11^{\circ} 11^{\prime \prime} \mathrm{N} \\
07^{\circ} 38^{\prime \prime} \mathrm{E}\end{array}$ & $\begin{array}{l}11^{\circ} 11^{\prime \prime} \mathrm{N} \\
07^{\circ} 38^{\prime \prime} \mathrm{E}\end{array}$ & $\begin{array}{ll}7^{\circ} & 21^{\prime} \mathrm{N} \\
3^{\circ} & 50{ }^{\prime} \mathrm{E}\end{array}$ & $\begin{array}{ll}4^{\circ} & 58^{\prime} \mathrm{N} \\
7^{\circ} & 55^{\prime} \mathrm{E}\end{array}$ \\
\hline Soil type & Alfisols & Alfisols & Alfisols & Alfisols & Inceptisols & Inceptisols & Alfisols & Ultisols & Ultisols & Alfisols & Ultisols \\
\hline Growing days & 180 & 180 & 150 & 120 & 90 & 90 & 190 & 150 & 150 & 180 & 270 \\
\hline $\begin{array}{l}\text { Annual rainfall } \\
(\mathrm{mm})\end{array}$ & 1195.4 & 1195 & 1101 & 981 & 800 & 800 & 1050 & 1011 & 1011 & 1278 & $>2500$ \\
\hline Agro-ecology & $\begin{array}{c}\text { Forest cum } \\
\text { derived } \\
\text { savanna }\end{array}$ & Forest & $\begin{array}{c}\text { Northern } \\
\text { Guinea } \\
\text { savanna }\end{array}$ & $\begin{array}{l}\text { Sudan } \\
\text { savanna }\end{array}$ & $\begin{array}{l}\text { Sudan } \\
\text { savanna }\end{array}$ & $\begin{array}{l}\text { Sudan } \\
\text { savanna }\end{array}$ & $\begin{array}{c}\text { Southern } \\
\text { Guinea } \\
\text { savanna }\end{array}$ & $\begin{array}{c}\text { Northern } \\
\text { Guinea } \\
\text { savanna }\end{array}$ & $\begin{array}{c}\text { Northern } \\
\text { Guinea } \\
\text { savanna }\end{array}$ & Forest & Forest \\
\hline
\end{tabular}


grain size was estimated in order to identify most relevant measure of stability for each of the traits.

\section{Data analysis}

In order to estimate yield, the following stability parameters were calculated:

Regression coefficient,

$$
b_{i}=1+\frac{\sum \mathrm{i}\left(X i j-\bar{X} i .-\bar{X}_{. j}+\bar{X}_{. .}\right)\left(\bar{X}_{. j}+\bar{X}_{. .}\right)}{\sum j\left(\bar{X} . j+\bar{X}_{. .}\right)^{2}}
$$

Mean of regression deviation,

$$
S d^{2}{ }_{i}=\frac{1}{E-2}\left[\sum i\left(X_{i j}-\bar{X}_{i .}-\bar{X}_{. j}+\bar{X}_{. .}\right)^{2}-(b i-1)^{2} \sum_{i}\left(\bar{X}_{. j}+\bar{X}_{. .}\right)^{2}\right]
$$

Coefficient of variation, $C V_{i}=\left(\frac{\sqrt{S i^{2}}}{\bar{X} i}\right) \times 100$

Wricke's ecovalence, $W_{i}=\sum_{i=1}^{n}\left(X i j-\bar{X}_{i .}-\bar{X}_{. j}+\bar{X}_{. .}\right)^{2}$
Where $X i j$ is the mean performance of genotype $i$ in environment $j . \bar{X}_{i}$. and $\bar{X}_{j}$ are the mean yield of genotype $i$ and environment $j$ respectively, and $X$ is the overall mean. $E$ is the number of environments.

\section{RESULTS}

\section{Grain yield}

The result for the analysis of variance for grain yield is shown in Table 3. It shows highly significant difference among the genotypes $(P<0.01)$. The highest mean yield across locations was recorded in IT93K-452-1 (0.89 t/ha) (Table 4). It out yielded the check, IT86D-719 by $0.15 \mathrm{t} / \mathrm{ha}$. However, not all the varieties yielded equally across the eleven locations. Some varieties were higher yielding in some locations but not in others. This is indicated by the analysis of variance where mean square for genotype by

Table 3. Mean squares for grain yield, days to pod maturity and seed size for early maturing cowpea varieties tested for two years and in different locations in Nigeria.

\begin{tabular}{lcccc}
\hline \hline \multirow{2}{*}{ Source } & \multirow{2}{*}{ Degrees of Freedom } & \multicolumn{3}{c}{ Mean Square } \\
\cline { 3 - 5 } & & Grain yield & Maturity & Seed size \\
\hline Genotypes & 7 & $379755.2^{* *}$ & $710.097^{* *}$ & $52.272^{* *}$ \\
Location & 9 & $359927.0^{* *}$ & $4040.771^{* *}$ & $190.315^{* *}$ \\
Genotype x Location & 63 & $264594.6^{* *}$ & $389.565^{* *}$ & $22.344^{* *}$ \\
\hline
\end{tabular}

**Stand for significant at the 0.01 probability level.

Table 4. Grain yield ( $\mathrm{t} / \mathrm{ha}$ ) of some early maturing varieties tested in a multi-environment evaluation in Nigeria.

\begin{tabular}{lcccccccccccc}
\hline \multirow{2}{*}{ Genotypes } & \multicolumn{10}{c}{ Locations } \\
\cline { 2 - 12 } & Abeokuta & Bauchi & Gombe & Ile-Ife & Kano 1 & Kano 2 & Mokwa & Samaru1 & Samaru 2 & Ibadan & Uyo & Mean \\
\hline IT93K-452-1 & 0.67 & 1.40 & 1.77 & 0.69 & 1.09 & 1.07 & 1.19 & 0.47 & 0.47 & 1.43 & 0.87 & $0.89 \mathrm{a}$ \\
IT95K-1543 & 0.56 & 1.60 & 1.72 & 0.49 & 1.36 & 1.02 & 0.92 & 0.35 & 0.27 & 1.74 & 0.50 & $0.87 \mathrm{ab}$ \\
IT93K-273-2-1 & 0.53 & 1.32 & 1.48 & 0.82 & 1.43 & 0.65 & 0.82 & 0.42 & 0.35 & 1.35 & 0.64 & $0.82 \mathrm{ab}$ \\
IT93K-129-4 & 0.73 & 1.16 & 2.06 & 0.76 & 1.01 & 0.46 & 0.85 & 0.30 & 0.19 & 1.26 & 1.03 & $0.80 \mathrm{ab}$ \\
IT86D-719 & 0.51 & 1.45 & 1.69 & 0.34 & 0.84 & 1.54 & 0.77 & 0.48 & 0.46 & 1.18 & 1.06 & $0.73 \mathrm{bc}$ \\
IT94K-410-2 & 0.69 & 1.21 & $\mathrm{x})$ & 0.67 & 1.38 & 0.39 & 0.77 & 0.51 & 0.38 & 1.23 & 0.54 & $0.66 \mathrm{dc}$ \\
IT95K-1455 & 0.82 & 1.32 & 1.40 & 0.76 & 1.00 & 0.13 & 0.96 & 0.34 & 0.34 & x) & 0.56 & $0.63 \mathrm{~cd}$ \\
IT90K-503-1 & 0.59 & 1.17 & 2.06 & 0.41 & 0.49 & 0.52 & 0.99 & 0.44 & 0.52 & 1.40 & 0.49 & $0.59 \mathrm{~d}$ \\
Location mean $^{\text {y) }}$ & $0.64 \mathrm{ef}$ & $1.33 \mathrm{~b}$ & $1.73 \mathrm{a}$ & $0.62 \mathrm{ef}$ & $1.08 \mathrm{c}$ & $0.55 \mathrm{fg}$ & $0.91 \mathrm{~d}$ & $0.41 \mathrm{~g}$ & $0.37 \mathrm{~g}$ & $1.40 \mathrm{~b}$ & $0.71 \mathrm{de}$ & 0.86 \\
\hline
\end{tabular}

${ }^{z)}$ Means of varieties which are designated by the same letters are not significantly different according to DMRT at the 0.05 probability level.

${ }^{\mathrm{y})}$ Location means which are designated by the same letters are not significantly different according to DMRT at the 0.05 probability level.

${ }^{\mathrm{x})}$ Missing value because of unavailable data due to unforeseen circumstances during the trial in these locations. 
location was highly significant (Table 3 ). For example, the variety IT95K-1543 was the highest yielding at Ibadan and Bauchi but not in the other remaining sites. Similarly, although the average yield of IT90K-503-1 was $0.59 \mathrm{t} / \mathrm{ha}$, it yielded over 2 tons/ha in Gombe. This shows the need for maintaining these locations for effective varietal selection.

According to Table 4, Gombe, situated in the Sudan Savanna, is the most productive location with an average grain yield of $1.73 \mathrm{t} / \mathrm{ha}$. This is followed by Ibadan with a grain yield of $1.40 \mathrm{t} / \mathrm{ha}$. This may seem surprising because Ibadan is situated at around $7^{\circ} \mathrm{N}$ outside the natural cowpea zones in the derived Savannah, however, rain pattern in September to October resembles the rainy regime of Sudan Savannah in July to October (Singh 1993). This facilitated the productivity of cowpea in that agro-ecology. Samaru, though in the Northern guinea savanna, a good ecology for cowpea (Singh 1993), turned out to be the least yielding location, $0.37-0.41 \mathrm{t} / \mathrm{ha}$. Similarly the yield for Kano2 was relatively low compared to Kano1. The cowpea was planted under intercrop with millet in Kano2 and with maize in Samaru1. This is not unexpected as the shading effect of the cereals reduce cowpea yields (Terao et al. 1997).

\section{Grain yield stability}

The result for stability analysis is shown in Table 5 . The result shows that no single genotype was better, based on the stability parameters. However, line IT93K-452-1 was identified as the most stable genotype based on its high grain yield: $b_{i}$ of unity, lowest value of $W_{i}$, greater than $0.800 R^{2}$ value and low $C V_{i}$ value $(<11 \%)$, and it can be grown all over the Nigerian cowpea belt. The next stable genotype is IT93K-273-2-1. The line IT90K-503-1 was the most unstable genotype in terms of grain yield for having the largest value of $W_{i}$. With lowest $b_{i}$ value $(0.600)$ the variety is also non responsive to the environment thereby giving low yield no matter what input was applied. However, its high $C V_{i}$ suggests that it is environment specific. Similarly, Ado and Ishiyaku (1999) used the magnitude of $b_{i}$ to classify pepper genotypes for stability of fruit yield.

\section{Maturity}

The result for the analysis of time taken to maturity is presented in Table 6 . There was highly significant difference among the lines for these traits. Similarly both the location and genotype by location interaction mean squares were highly significant $(P<0.001)$. This suggests that some genotypes matured earlier in some locations but were relatively late in other locations. For example one of the two earliest genotypes, IT90K-503-1, matured in 63 days on the average (Table 6). However, it matured two and three weeks later in Mokwa and Kano, respectively. IT95K-1543 was the latest maturity line (Table 6). Bauchi and Samaru 1 were the earliest (63 days) and latest (83 days) cowpea maturity environments, respectively.

Table 5. Means and estimates of stability parameters for grain yield ( $t /$ ha) of some early maturing cowpea varieties tested in different agro-ecologies in Nigeria.

\begin{tabular}{lcccccc}
\hline \hline \multirow{2}{*}{ Genotypes } & \multicolumn{3}{c}{ Parameters $^{\mathrm{z}}$} \\
\cline { 2 - 7 } & Mean & $b_{i}$ & $S d^{2}{ }_{i}$ & R-square & $C V_{i}$ & $W_{i}$ \\
\hline IT93K-452-1 & 0.89 & 1.016 & 10347.64 & 0.826 & 50.3 & 1600433.68 \\
IT95K-1543 & 0.87 & 1.203 & -2080.29 & 0.766 & 63.3 & 3519134.53 \\
IT93K-273-2-1 & 0.82 & 1.045 & 8408.89 & 0.801 & 56.9 & 1993556.29 \\
IT93K-129-4 & 0.80 & 1.115 & -10928.64 & 0.860 & 59.5 & 3245170.67 \\
IT86D-719 & 0.73 & 0.929 & -2128.57 & 0.662 & 62.1 & 3245170.67 \\
IT94K-410-2 & 0.66 & 0.930 & 1764.66 & 0.519 & 62.2 & 3771486.70 \\
IT95K-1455 & 0.63 & 0.881 & -2128.12 & 0.616 & 67.2 & 3068034.64 \\
IT90K-503-1 & 0.59 & 0.600 & 1893.7 & 0.309 & 60.5 & 4504546.79 \\
Grand Mean & 0.75 & 0.858 & 572.14 & 0.595 & 53.56 & 2771948.22 \\
\hline
\end{tabular}

${ }^{\text {z) }} b_{i}, S d^{2}, C V_{i}$, and $W_{i}$ stand for regression coefficient, deviation from regression, coefficient of variability, and Wricke's ecovalence, respectively. 
Table 6. Days taken to $90 \%$ pod maturity for early maturing cowpea varieties tested in a multi-environment evaluation in Nigeria.

\begin{tabular}{|c|c|c|c|c|c|c|c|c|c|c|c|}
\hline \multirow{2}{*}{ Genotypes } & \multicolumn{11}{|c|}{ Locations } \\
\hline & Abeokuta & Bauchi & Ile-Ife & Kano 1 & Kano 2 & Mokwa & Samaru1 & Samaru 2 & Ibadan & Uyo & Mean $^{\text {z) }}$ \\
\hline IT93K-452-1 & 75.3 & 57.6 & 70.0 & 62.6 & 68.0 & 76.0 & 81.6 & 76.6 & 65.0 & 68.0 & $71.0 \mathrm{ab}$ \\
\hline IT95K-1543 & 77.0 & 62.0 & 69.0 & 75.1 & 72.0 & 76.0 & 86.0 & 79.0 & 63.0 & 68.0 & $74.7 \mathrm{a}$ \\
\hline IT93K-273-2-1 & 77.8 & 66.0 & 70.0 & 65.3 & 70.0 & 75.6 & 83.1 & 76.6 & 65.0 & 68.0 & $73.0 \mathrm{ab}$ \\
\hline IT93K-129-4 & 76.5 & 63.0 & 68.6 & 70.3 & 74.3 & 77.0 & 81.3 & 78.0 & 65.5 & 68.0 & $73.3 \mathrm{ab}$ \\
\hline IT86D-719 & 75.3 & 59.3 & 68.6 & 68.6 & 69.3 & 76.6 & 85.5 & 83.3 & 66.5 & 68.0 & $73.3 \mathrm{ab}$ \\
\hline IT94K-410-2 & 75.8 & 65 & 69.3 & 65.0 & 70.0 & 74.0 & 82.0 & 80.0 & 64.0 & 68.0 & $67.4 \mathrm{bc}$ \\
\hline IT95K-1455 & 75.3 & 67 & 68.0 & 70.0 & 72.0 & 75.0 & 84.5 & 80.3 & 68.0 & 68.0 & $64.7 \mathrm{c}$ \\
\hline IT90K-503-1 & 66.6 & 61 & 68.6 & 52.3 & 50.0 & 77.0 & 81.5 & 80.3 & 66.5 & 75.0 & $62.8 \mathrm{c}$ \\
\hline Location mean ${ }^{\mathrm{y})}$ & $75.0 \mathrm{bc}$ & $62.6 \mathrm{e}$ & $69.0 \mathrm{~cd}$ & $66.1 \mathrm{~d}$ & $68.2 \mathrm{~d}$ & $76.0 \mathrm{bc}$ & $83.2 \mathrm{a}$ & $79.2 \mathrm{ab}$ & $65.4 \mathrm{~d}$ & $69.0 \mathrm{dc}$ & 71.3 \\
\hline
\end{tabular}

${ }^{2)}$ Means of varieties which are designated by the same letters are not significantly different according to DMRT at the 0.05 probability level.

${ }^{y)}$ Location means which are designated by the same letters are not significantly different according to DMRT at the 0.05 probability level.

Table 7. Means and estimates of stability parameters for days to pod maturity of some early maturing cowpea varieties tested in different agro-ecologies in Nigeria.

\begin{tabular}{lccccc}
\hline \hline \multirow{2}{*}{ Genotypes } & \multicolumn{5}{c}{ Parameters $^{\mathrm{z})}$} \\
\cline { 2 - 6 } & Mean & $b_{i}$ & R-square & $C V_{i}$ & $W_{i}$ \\
\hline IT93K-452-1 & 71 & 0.585 & 0.780 & 11.0 & 1333.78 \\
IT95K-1543 & 75 & 0.534 & 0.635 & 10.5 & 1890.61 \\
IT93K-273-2-1 & 73 & 0.444 & 0.546 & 9.7 & 2348.50 \\
IT93K-129-4 & 73 & 0.431 & 0.699 & 8.2 & 2005.36 \\
IT86D-719 & 73 & 0.621 & 0.804 & 11.1 & 1177.45 \\
IT94K-410-2 & 67 & 1.692 & 0.866 & 32.8 & 4514.99 \\
IT95K-1455 & 65 & 1.933 & 0.839 & 39.7 & 7770.41 \\
IT90K-503-1 & 63 & 1.803 & 0.760 & 38.5 & 8279.27 \\
Grand mean & 70 & 1.005 & 0.741 & 20.2 & 3665 \\
\hline
\end{tabular}

${ }^{\mathrm{z})} b_{i}, S d^{2}{ }_{i}, C V_{i}$, and $W_{i}$ stand for regression coefficient, deviation from regression, coefficient of variability, and Wricke's ecovalence, respectively.

The result of the stability analysis for days to maturity is presented in Table 7. The result shows that $b_{i}$ varied from less than unity in lines like IT93K-273-2-1 to greater than unity in IT95K-1455. The lines IT93K-452-1, IT95K-1543, IT93K-273-2-1, IT93K-129-4 and the check IT86D-719 all have $b_{i}$ values less than unity $(0.444-0.621)$. This suggests that irrespective of the climatic characteristics of an environment, where this test was conducted, they come into maturity around their genetic potential. This suggests not only the photo-insensitive nature of these lines but that they are also insensitive to temperature (within the range in this experiment) in respect of reproductive development.
This trend of stability on the basis of $b_{i}$ is similar to that using $C V_{i}$ and $W_{i}$. The genotypes IT93K-129-4, IT93K-273-2-1, IT95K-1543, IT93K-452-1 and IT86D-719 exhibited stable maturity across the environments.

However, the remaining lines, IT94K-410-2, IT95K-1455 and IT90K-503-1, even though relatively early maturing ( $<70$ days), have $b_{i}$ values larger than unity. Similarly these genotypes have relatively high $C V_{i}$ and $W_{i}$ values indicating unstable maturity time. These genotypes are therefore, sensitive to photothermal conditions of the environments with regard to time to maturity. To get them to mature early, they should be planted when temperatures 
are near optimum, around $28^{\circ} \mathrm{C}$ and photoperiod shorter than the critical value of $12 \mathrm{hd}^{-1}$ as reported by Craufurd et al. (1996)

\section{Grain size}

The results of the analysis of variance for grain size are presented in Table 8 . The result shows highly significant differences among the genotypes, location as well as the interactions between genotypes and locations. Out of the seven locations where the lines were evaluated for this trait largest grain size was observed at Mokwa. The smallest grains were observed in Bauchi (12 g/100 seeds) and Uyo (13 g/100 seeds). The line, IT95K-1543 had the largest grain size of $16 \mathrm{~g} / 100$ seeds while IT90K-503-1 and IT93K-273-2-1 had the smallest grain size of $12 \mathrm{~g} / 100$ seeds each (Table 8). However as indicated by the statistical significance of the interaction between genotypes and locations for this trait, grain size of some lines differed from one location to another. For example, the line IT94K-410-2 even though had mean grain size of 14.2 $\mathrm{g} / 100$ seeds but it measured up to $18 \mathrm{~g}$ in Mokwa. Similarly, IT93K-452-1 with an average of $15 \mathrm{~g}$ had grain size of up

Table 8. Grain size (g/100 seeds) for early maturing cowpea varieties tested in multi-environment evaluation in Nigeria.

\begin{tabular}{lcccccccc}
\hline \multirow{2}{*}{ Genotypes } & \multicolumn{9}{c}{ Locations } \\
\cline { 2 - 9 } & Abeokuta & Bauchi & Ile-Ife & Mokwa & Samaru1 & Samaru 2 & Uyo $^{\text {Mean }}{ }^{\text {z) }}$ \\
\hline IT93K-452-1 & 15.4 & 12.0 & 19.3 & 16.5 & 16.0 & 16.6 & 15.3 & $15.2 \mathrm{ab}$ \\
IT95K-1543 & 15.0 & 12.5 & 15.3 & 17.6 & 18.3 & 18.4 & 15.0 & $16.1 \mathrm{a}$ \\
IT93K-273-2-1 & 14.1 & 9.0 & 12.0 & 15.0 & 11.5 & 11.6 & 10.0 & $12.2 \mathrm{~b}$ \\
T93K-129-4 & 14.5 & 11.6 & 14.0 & 15.5 & 12.4 & 13.4 & 11.6 & $13.2 \mathrm{ab}$ \\
IT86D-719 & 15.5 & 14.2 & 12.0 & 16.5 & 12.7 & 13.4 & 12.0 & $13.1 \mathrm{ab}$ \\
IT94K-410-2 & 17.1 & $\mathrm{x})$ & 14.1 & 18.1 & 14.0 & 15.5 & 13.6 & $14.2 \mathrm{ab}$ \\
IT95K-1455 & 16.0 & 16.5 & 11.0 & 15.2 & 16.4 & 16.7 & 14.0 & $14.0 \mathrm{ab}$ \\
IT90K-503-1 & 13.9 & x) & 14.0 & 16.4 & 13.5 & 10.3 & 10.3 & $12.3 \mathrm{~b}$ \\
Location mean ${ }^{\text {y) }}$ & $15.2 \mathrm{ab}$ & $12.6 \mathrm{~b}$ & $14.1 \mathrm{ab}$ & $16.3 \mathrm{a}$ & $15.0 \mathrm{ab}$ & $14.3 \mathrm{ab}$ & $13.0 \mathrm{ab}$ & 11.03 \\
\hline
\end{tabular}

${ }^{\text {z) }}$ Means of varieties which are designated by the same letters are not significantly different according to DMRT at the 0.05 probability level.

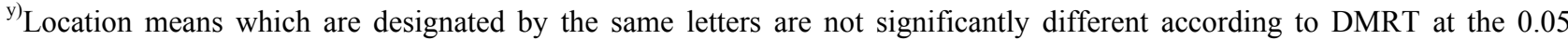
probability level.

${ }^{\mathrm{x})}$ Missing value because of unavailable data due to unforeseen circumstances during the trial in these locations.

Table 9. Means and estimates of stability parameters for grain size (g/100 seeds) of some early maturing cowpea varieties tested in different agro-ecologies in Nigeria.

\begin{tabular}{|c|c|c|c|c|c|c|}
\hline \multirow{2}{*}{ Genotypes } & \multicolumn{6}{|c|}{ Parameters ${ }^{\mathrm{z})}$} \\
\hline & Mean & $b_{i}$ & $S d_{i}^{2}$ & R-square & $C V_{i}$ & $W_{i}$ \\
\hline IT93K-452-1 & 15.2 & 0.596 & 0.176 & 0.388 & 18.0 & 176.74 \\
\hline IT95K-1543 & 16.1 & 0.444 & -0.565 & 0.385 & 12.6 & 152.53 \\
\hline IT93K-273-2-1 & 12.2 & 0.698 & -0.637 & 0.627 & 20.6 & 93.24 \\
\hline IT93K-129-4 & 13.2 & 0.537 & -0.826 & 0.559 & 15.5 & 108.08 \\
\hline IT86D-719 & 13.1 & 0.842 & -0.224 & 0.624 & 23.1 & 110.48 \\
\hline IT94K-410-2 & 14.2 & 1.858 & -1.115 & 0.964 & 39.0 & 197.42 \\
\hline IT95K-1455 & 14.0 & 1.444 & 1.716 & 0.661 & 27.4 & 310.00 \\
\hline IT90K-503-1 & 12.3 & 1.726 & -0.797 & 0.929 & 42.0 & 172.59 \\
\hline Grand mean & 11.03 & 0.905 & -0.252 & 0.571 & 22.02 & 146.79 \\
\hline
\end{tabular}

${ }^{2)} b_{i}, S d^{2}, C V_{i}$, and $W_{i}$ stand for regression coefficient, deviation from regression, coefficient of variability, and Wricke's ecovalence, respectively. 
to $19 \mathrm{~g}$ in Ile-Ife. However, other genotypes such as IT93K-129-4 showed near constant grain size over these test locations.

The result for stability analysis for grain size is presented in Table 9. The result shows that only three lines, IT94K-410-2, IT95K-1455 and IT90K-503-1 had $b_{i}$ values of greater than unity, 1.858, 1.444 and 1.726, respectively. This is supported by a corresponding high $C V_{i}$ and $W_{i}$ values for all the three lines. This suggests that grain size in those lines is environment dependent. For the remaining five test lines however, the $b_{i}$ values were less than unity (0.444-0.842). Similarly the deviations from regression $S d^{2}{ }_{i}$ were smaller than unity. This suggests that the environment has insignificant effect on the grain size of IT93K-452-1, IT95K-1543, IT93K-273-2-1, IT93K-129-4 and IT86D-719.

The result of the test of association between grain yield and the various stability parameters is presented in Table 10. It shows that $b_{i}$, and $R^{2}$ where highly significantly correlated with grain yield. While $S d^{2}{ }_{i}$ and $W_{i}$ were significantly negatively correlated with grain yield. The stability parameters $b_{i}$ is only correlated with $R^{2}$ meaning to measure the stability of grain yield, score on all the other parameters $S d^{2}{ }_{i}, W_{i}$ and $C V_{i}$ are required.

The result of the test of association between the stability parameters and days to maturity in Table 11 . The result shows that maturity is highly negatively correlated with $b_{i}$, $C V_{i}$ and $W_{i}$ but not with $R^{2}$. In addition the parameters $C V_{i}$ and $W_{i}$ were highly correlated with $b_{i}$ suggesting that scoring stability for maturity on $b_{i}$ alone is as good as scoring on either $C V_{i}$ or $W_{i}$. Since $C V_{i}$ is highly significant correlated with $W_{i}$ (Table 11). These results suggest that the stability of genotypes for time to maturity can be best measured by $b_{i}$.

Result of the analysis of association between grain size and the various stability parameters were not significant (Table 12). However, $b_{i}$ is highly correlated with both $C V_{i}$ and $R^{2}$ Based on these results it is not clear which of the

Table 10. Correlation coefficients between mean grain yield and stability parameters for early maturing cowpea varieties evaluated in Nigeria.

\begin{tabular}{lcccccc}
\hline \hline Parameters ${ }^{\mathrm{z}}$ & Yield & $b_{i}$ & $S d^{2}$ & $C V_{i}$ & $W_{i}$ & R-square \\
\hline Yield & 1.000 & $0.862^{* *}$ & $-0.738^{*}$ & -0.593 & $-0.709^{*}$ & $0.889^{* *}$ \\
$b_{i}$ & & 1.000 & -0.500 & -0.153 & -0.476 & $0.761^{*}$ \\
$S d^{2}{ }_{i}$ & & 1.000 & 0.653 & $0.977^{* *}$ & $-0.863^{* *}$ \\
$C V_{i}$ & & & 1.000 & 0.603 & -0.401 \\
$W_{i}$ & & & & 1.000 & $-0.879^{* *}$ \\
R-Square & & & & & 1.000 \\
\hline
\end{tabular}

${ }^{2)} b_{i}, S d^{2}{ }_{i}, C V_{i}$, and $W_{i}$ stand for regression coefficient, deviation from regression, coefficient of variability, and Wricke's ecovalence, respectively.

* and ** Stand for significant at the 0.05 and 0.01 probability level, respectively.

Table 11. Correlation coefficients between days to pod maturity and stability parameters in early maturing cowpea varieties evaluated in Nigeria.

\begin{tabular}{lccccc}
\hline \hline Parameters $^{\mathrm{z})}$ & Days to Maturity (DM) & $b_{i}$ & $C V_{i}$ & $W_{i}$ & $\mathrm{R}$-square \\
\hline $\mathrm{DM}$ & 1.000 & $0.943^{*}$ & $-0.957^{* *}$ & $-0.946^{* *}$ & -0.566 \\
$b_{i}$ & & 1.000 & $0.996^{* *}$ & $0.925^{* *}$ & 0.657 \\
$C V_{i}$ & & 1.000 & $0.951^{* *}$ & 0.606 \\
$W_{i}$ & & & & 1.000 & 0.395 \\
R-Square & & & & 1.000 \\
\hline
\end{tabular}

${ }^{\text {z) }} b_{i}, S d^{2}, C V_{i}$, and $W_{i}$ stand for regression coefficient, deviation from regression, coefficient of variability, and Wricke's ecovalence, respectively. 
Table 12. Correlation coefficients between grain size and stability parameters in early maturing cowpea varieties evaluated in Nigeria.

\begin{tabular}{lcccccc}
\hline \hline Parameters $^{\mathrm{z})}$ & Grain size (GS) & $b_{i}$ & $S d^{2}$ & $C V_{i}$ & $W_{i}$ & R-Square \\
\hline $\mathrm{GS}$ & 1.000 & -0.309 & 0.174 & -0.393 & 0.288 & -0.566 \\
$b_{i}$ & & 1.000 & 0.034 & $0.983^{*}$ & 0.566 & $0.916^{* *}$ \\
$S d^{2}{ }_{i}$ & & & 1.000 & 0.131 & 0.285 & -0.380 \\
$C V_{i}$ & & & & 1.000 & 0.476 & $0.891^{* *}$ \\
$W_{i}$ & & & & & 1.000 & 0.380 \\
R-square & & & & & 1.000 \\
\hline
\end{tabular}

${ }^{2)} b_{i}, S d^{2}, C V_{i}$, and $W_{i}$ stand for regression coefficient, deviation from regression, coefficient of variability, and Wricke's ecovalence, respectively.

**Stand for significant at the 0.01 probability level.

parameters is best suitable for scoring genotypes for stability of grain size.

\section{DISCUSSION}

The result of the multi-environment testing of these elite cowpea lines have revealed that there is a huge interaction between genotypes and the locations of testing for all the three traits, grain yield, maturity and grain size. This is not surprising as the test environments span not only a wide area of over $800 \mathrm{~km}$ along the North-to-East transect of Nigeria $\left(7^{\circ}-12^{\circ} \mathrm{N}\right)$ but also covers from the dry savanna to the moist forest ecological zones, with annual total rainfall of about $800 \mathrm{~mm}$ and more than $2000 \mathrm{~mm}$, respectively. This further underscores the need to evaluate cowpea lines in different locations. A line such as IT93K-452-1 with an average yield of almost a ton per hectare has a stable yield based on its stability parameters and can be recommended for production in all the agro-ecologies in Nigeria. In addition those with less stable yield with equally high mean yield such as IT93K-129-4 can yield as high as 2 tones/ha in specific environments even though they may exhibit low productivity in other environments. Such lines should be released for production in only those specific locations. The line IT93K-273-2-1 is the most suitable for production at Ile Ife while the best lines for the forest zones, like Uyo are IT93K-129-4 and the check, IT86D-719. The average yield of $0.75 \mathrm{t} / \mathrm{ha}$ (Table 7) may look low, however, given the range of $0.15-2.06 \mathrm{t} / \mathrm{ha}$ (Table 4 ), shows that the real yield potential of early cowpea varieties is high. Some varieties can yield as high as 2 tones/ha.

In terms of duration to maturity early maturing varieties mature earliest in 56 days and can be delayed to 83 days depending on the location. The variation in this trait is around $50 \%$ due to the interaction of genotypes with locations. Generally warmer locations such as Bauchi were earlier in maturity compared to relatively cooler locations like Mokwa and Samaru. Craufurd et al. (1996) and Ehlers and Hall (1997) both concluded that for some genotypes of cowpea if photoperiod is not limiting temperature is the determinant for rate of reproductive development. Craufurd et al. (1996) gave around $28^{\circ} \mathrm{C}$ as the optimum average temperature for reproductive development of cowpea. Although the temperatures during this evaluation were apparently sub-optimal some sites might have influenced rate of reproductive development more than others. This necessitates the testing of lines in specific sites before final recommendation.

As important as grain size this work has shown that it can be influenced by environmental condition under which it is estimated. Although variation among the genotypes is statistically significant, the range for seed size between locations is narrow (12-16 g/100 seeds). In an earlier study, Ishiyaku and Singh (2003) reported a grain size of up to 33 $\mathrm{g} / 100$ seeds. The range observed here could be termed medium size. This means that early maturity is synonymous with medium grain size. 


\section{ACKNOWLEDGEMENTS}

The development of a variety involves the contribution of several individuals and corporate organizations. We therefore wish to express our sincere gratitude to the International Institute of Tropical Agriculture (ITTA), Ibadan, Nigeria for providing IAR with the initial germplasm for the development of these varieties. We also wish to appreciate the immense contributions made by our numerous collaborators in the Nationally Coordinated Research Project (NCRP) particularly, IAR\&T, UNAAB, LCRI, KNARDA, KTARDA, ATBU, JARDA and others for assisting in the conduct of the on-farm or on-station evaluations. We thank the Director Institute for Agricultural Research, A.B.U. Zaria, Dr S.M. Misari and the Program Leader Legume and Oilseeds, Prof. C.I. Amatobi for all their support. The contributions of SG 2000 and PEDUNE Project in the conduct of the on-farm trials are highly appreciated.

\section{REFERENCES}

Ado SG, Ishiyaku MF. 1999. Genotype x environment interaction in pepper (Capsicum annuum L.) evaluation trials in the Nigerian savannas. Nigerian Journal of Genetics. 14: 78-86.

Bado BV, Batuiono A, Cescas MP. 2006. Assessment of cowpea and groundnut contributions to soil fertility and succeeding sorghum yields in the Guinean savannah zone of Burkina Faso (West Africa). Biol. Fert. Soils. 43: 171-176.

Bagayoko M, Mason SC, Traore S. 1998. The role of cowpea on pearl millet yield, $\mathrm{N}$ uptake and soil nutrient status in millet-cowpea rotation in Mali, p. 109-114. In: G. Renard, A. Neef, K. Becker, M. von Oppen (eds.). Proceedings of the regional workshop on Soil fertility management in West African land-use systems. Margraf Verlag Weikersheim, Germany.

Carsky RJ, Vanlauwe B, Lyasse, O. 2002. Cowpea rotation as a resource management technology for cereal-based systems in the savannas of West Africa, p. 252-265. In: C.A. Fatokun, S.A. Tarawali, B.B. Singh, P.M. Kormawa and M. Tamo (eds.). Challenges and opportunities for enhancing sustainable cowpea production. Proceedings of the world cowpea conference III held at the International Institute of Tropical Agriculture (IITA), Ibadan, Nigeria.

Craufurd PQ, Aiming Q, Summerfield RJ, Ellis RH, Roberts EH. 1996. Development in cowpea (Vigna unguiculata). III. Effects of temperature and photoperiod on time to flowering in photoperiod-sensitive genotypes and screening for photothermal responses. Expl. Agric. 32: 29-40.

Eberhart SA, Russell WA. 1966. Stability parameters for comparing varieties. Crop Sci. 6: 36-40.

Ehlers JD, Hall AE. 1997. Cowpea. Crop. Res. 53: 187-204.

Emechebe AM, Lagoke STO. 2002. Recent advances in research on cowpea diseases, p. 94-123. In: CA. Fatokun, SA. Tarawali, BB. Singh, PM. Kormawa, M. Tamo (eds.). Challenges and opportunities for enhancing sustainable cowpea production. Proceedings of the world cowpea conference III held at the International Institute of Tropical Agriculture (IITA), Ibadan, Nigeria.

FAOSTAT 2002. Food and Agriculture Statistical Database. http://www.fao.org/faostat

Fery RL, Singh BB. 1997. Cowpea genetics: a review of recent literature, p. 13-29. In: BB. Singh, DR. Mohan Raj, KE. Dashiell, LEN. Jackai (eds.). Advances in cowpea research. Copublication of IITA and JIRCAS. IITA, Ibadan, Nigeria.

Finlay KW, Wilkinson GN. 1963. The analysis of adaptation in plant-breeding programme. Aust. J. Agr. Res. 14: 742-754.

Francis TT, Kannenberg LW. 1978. Yield stability studies in short-season maize. I. A descriptive method of grouping genotypes. Can. J. Plant Sci. 58: 1029-1034.

Ibro G, Fulton J, Lowenberg-DeBoer J. 2006. Factors affecting success for women entrepreneurs in West Africa: The case of kosai, a value added cowpea product. Selected paper prepared for presentation at 2006 American Agricultural Economics Association Annual Meeting, Long Beach, California. Accessed from www.researchgate.net/publication/23506442.

Ishiyaku MF, Singh BB. 2003. Genetical studies and transgressive segregation for large seeds in cowpea [Vigna unguiculata (L.) WALP.]. MUARIK Journal. 2: 74-88.

Ishiyaku MF. 2001. In search of a viable food security option for Nigeria. A seminar paper presented at the IITA Kano 
station public seminar series delivered on 26 June 2001, IITA Kano Station, Kano, Nigeria.

Langyintuo AS, Lowenberg-DeBoer J, Faye M, Lambert D, Ibro G, Moussa B et al. 2003. Cowpea supply and demand in West and Central Africa. Field Crop. Res. 82: 215-231.

Lin CS, Binns MR, Lefkovitch LP. 1986. Stability analysis: Where do we stand? Crop Sci. 26: 894-900.

Mustapha S. 2003. The importance of Nigerian indigenous genetic resource for economic empowerment. A keynote address delivered at the Genetic Society of Nigeria Annual Conference held at the University of Agriculture, Makurdi, Nigeria on 5-6 December 2003.

Quin FM. 1997. Introduction. p. ix-xv. In: BB. Singh, DR. Mohan Raj, KE. Dashiell, LEN. Jackai (eds.). Advances in cowpea research. Copublication of International Institute of Tropical Agriculture (IITA) and Japan International Research Center for Agricultural Sciences (JIRCAS). IITA, Ibadan, Nigeria John Willey and Sons. Chichester, U.K.

SAS Institute. 1996. SAS/STAT user's guide. v. 6, 4th ed. SAS Inst. Cary, NC.

Singh BB. 1993. Cowpea breeding. In archival report (1988-1992) of grain legume improvement program. IITA, Ibadan, Nigeria. pp. 10-53.

Singh BB. 2002. Recent genetic studies in cowpea, p. 3-13. In: CA. Fatokun, SA. Tarawali, BB. Singh, PM. Kormawa, M. Tamo (eds.). Challenges and opportunities for enhancing sustainable cowpea production. Proceedings of the world cowpea conference III held at the International Institute of Tropical Agriculture (IITA), Ibadan, Nigeria.

Singh BB, Ehlers JD, Sharma B. Freire Filho FR. 2002. Recent progress in cowpea breeding. In Challenges and opportunities for enhancing sustainable cowpea production, p. 22-40. In: CA. Fatokun, SA. Tarawali, BB. Singh, PM. Kormawa, M. Tamo (eds.). Proceedings of the world cowpea conference III held at the International Institute of Tropical Agriculture (IITA), Ibadan, Nigeria.

Tarawali SA, Singh BB, Peters M, Blade SF. 1997. Cowpea haulms as fodder, p. 313-325. In: BB. Singh, DR. Mohan Raj, KE. Dashiell, LEN. Jackai (eds.). Advances in cowpea research. Copublication of International Institute of Tropical Agriculture (IITA) and Japan International Research Center for Agricultural Sciences (JIRCAS). IITA, Ibadan, Nigeria.

Terao T, Watanabe I, Matsunaga R, Hakoyama S, Singh BB. 1997. Agro-physiological constraints in intercropped cowpea: an analysis, p. 129-140. In: BB. Singh, DR. Mohan Raj, KE. Dashiell, LEN. Jackai (eds.). Advances in cowpea research. Copublication of International Institute of Tropical Agriculture (IITA) and Japan International Research Center for Agricultural Sciences (JIRCAS). IITA, Ibadan, Nigeria.

Wricke G. 1962. On the method of understanding biological diversity in field research. Z. Pflanzenzucht. 47: 92-96. 